Jurnal Care Vol .6, No.2,Tahun 2018

\title{
Penerapan Modifikasi Psikoedukasi Pada \\ Penderita Diabetes Mellitus Tipe2
}

\author{
Nailiy Huzaimah ${ }^{1}$ \\ ${ }^{1}$ Universitas Wiraraja Sumenep \\ e-mail: nailiy.huzaimah@gmail.com
}

\begin{abstract}
Controlled blood glucose level is one of the success indicator of the diabetes management. A good comprehension about diabetes and family support are needed to encourage and strengthen the effort of individuals to achieved good behavioral diabetes self-management, which helped to control blood glucose level. This study aimed to determine the Psychoeducation Modification's effects on behavioral diabetes selfmanagement, family support, and blood glucose level of people with type 2 diabetes mellitus (T2DM).

This study used pre and post test control group design. Respondents of this research are population with T2DM and their families who are undergoing outpatient treatment at Internal Medicine Outpatient Unit of Dr. H. Moh. Anwar Sumenep Hospital $(n=40)$. Collecting data included the patient's behavioral self-management of diabetes, family support, and random blood glucose level. Data collection used questionnaires and the laboratory test of blood glucose level. Results of statistical test with Mann Whitney $U$ test showed the differences in family support between the treatment group and the control group. Results of different test independent samples in the treatment group using paired T-test and Wilcoxon signed rank test showed that Psychoeducation Modification improved behavioral self-management of diabetes $(p=0,004)$, family support $(p=0.001)$ and random blood glucose level $(p=0,013)$ of people with T2DM. Psychoeducation modifications need to be implemented by health provider, particularly nursing staff to help people with T2DM improving their diabetes self-management behaviors, to achieve controled blood glucose level.
\end{abstract}

Keywords: behavioral self-management; family support; blood glucose level; psychoeducation, type 2 diabetes mellitus

\begin{abstract}
ABSTRAK
Kadar glukosa darah terkontrol merupakan salah satu indikator kesuksesan pengelolaan diabetes mellitus tipe 2 (DMT2). Pemahaman yang komprehensig tentang diabetes dan dukungan keluarga yang baik sangat dibutuhkan untuk mendorong dan menguatkan usaha individu untuk menerapkan pengelolaan diabetes mandiri, yang nantinya akan berdampak pada kadar glukosa darah penderita DMT2. Tujuan penelitian ini adalah untuk mengetahui pengaruh Modifikasi Psikoedukasi (MP) terhadap pengelolaan diabetes mandiri, dukungan keluarga, serta kadar glukosa darah (KGD) penderita DMT2. Penelitian ini menggunakan quasy experiment, pre and post test control group design. Responden penelitian adalah penderita DMT2 dan keluarganya yang sedang menjalani rawat jalan di Poli Penyakit Dalam RUSD Dr. H. Moh. Anwar Sumenep ( $\mathrm{n}=40)$. Pengumpulan data meliputi perilaku pengelolaan diabetes mandiri, dukungan keluarga, dan kadar glukosa darah acak penderita DMT2 dengan menggunakan kuesioner dan pemeriksaan laboratorium kadar glukosa darah.
\end{abstract}


Analisis statistik menggunakan uji beda dengan nilai $\alpha<0,05$. Hasil Mann Whitney $U$ test menunjukkan ada perbedaan pada variabel dukungan keluarga antara kelompok perlakuan dan kelompok kontrol. Hasil uji beda sampel independen pada kelompok perlakuan menggunakan Paired $T$ test dan Wilcoxon signed rank test menunjukkan bahwa pemberian Modifikasi Psikoedukasi meningkatkan perilaku pengelolaan diabetes mandiri $(p=0,004)$, dukungan keluarga $(\mathrm{p}=0,001)$, dan KGD $(\mathrm{p}=0,013)$ penderita DMT2.Pemberian MP perlu diterapkan oleh tenaga kesehatan, khususnya perawat dalam membantu penderita DMT2 meningkatkan perilaku pengelolaan mandiri diabetes untuk mencapai kadar glukosa darah yang terkontrol dengan mengikutsertakan keluarga.

Kata kunci: perilaku pengelolaan diabetes mandiri; dukungan keluarga; kadar glukosa darah; psikoedukasi; diabetes mellitus tipe 2

\section{PENDAHULUAN}

Metode dan pendekatan yang efektif dalam memberikan pendidikan diabetes dan pelatihan mengelola diabetes secara mandiri sangat dibutuhkan. Banyak ditemukan penderita DMT2 telah mendapatkan pendidikan diabetes akan tetapi belum mampu mengontrol glukosa darah bahkan sudah mengarah pada komplikasi. Hal ini menunjukkan bahwa pendidikan diabetes yang diberikan selama ini di pelayanan kesehatan masih kurang efektif karena tidak menghasilkan perubahan perilaku individu. Melatih penderita DMT2 tentang cara mengelola diabetes secara mandiri dengan mengikutsertakan keluarga untuk memberikan dukungan, merupakan bagian yang dibutuhkan dalam serangkaian kegiatan pendidikan diabetes.

Seiring dengan prevalensi diabetes global dan nasional yang terus meningkat, daerah lokal seperti Sumenep-Madura juga mengalami peningkatan prevalensi kejadian diabetes berikut juga komplikasinya. Hasil rekapitulasi 10 penyakit terbanyak di Poli Rawat Jalan RSUD dr. H. Moh. Anwar Sumenep pada bulan Januari sampai dengan Juni 2013 di Poli Interne didapatkan bahwa penyakit DMT2 menempati angka tertinggi dengan jumlah 1.723. Angka kunjungan DMT2 mengalami peningkatan setiap tahun, yaitu 2.391 pada tahun 2014 dan menjadi 3.904 pada tahun 2015. Angka DMT2 dengan komplikasi juga meningkat dari 2.148 pada tahun 2014 menjadi 3.892 pada tahun 2015 (rekapitulasi data RSUD dr. H. Moh Anwar Sumenep tahun 2016). Hasil studi rekam medik dan wawancara awal pada 20 orang penderita diabetes mellitus tipe 2 (DMT2) di Poli Penyakit Dalam RSUD dr. H. Moh. Anwar Sumenep yang dilakukan pada bulan Februari 2016 ditemukan $85 \%$ penderita DMT2 yang pernah mendapatkan pendidikan diabetes 
memiliki perilaku pengelolaan diabetes mandiri yang kurang baik dan kadar glukosa darah tidak terkontrol pada.

Diabetes memberikan pengaruh besar terhadap kehidupan individu penderita diabetes, keluarganya, dan sistem layanan kesehatan (Al-Khawaldeh, Al-Hassan, \& Froelicher, 2012). Diabetes yang tidak terkontrol telah banyak menyebabkan berbagai komplikasi seperti penyakit jantung, stroke, tekanan darah tinggi, kebutaan, penyakit ginjal, penyakit sistem saraf, amputasi kaki, dan kematian dini serta tidak jarang menyebabkan masalah keuangan (financial burden) dan menurunkan kualitas hidup (Sratton et al., 2000; Coffey et al., 2002).

Penelitian masih terus dikembangkan dengan harapan adanya perubahan perilaku pada penderita DMT2. Beberapa pengembangan program edukasi diabetes yang pernah diteliti di luar negeri antara lain adalah Diabetes Self Management Education (DSME), tele-health, program Point of Service Diabetes Education, konseling, program psikoedukasi internet, program edukasi kelompok terstruktur, Problem Solving-Based Diabetes SelfManagement Training, dan program Study of Women's Emotions and Evaluation of a
Psychoeducational (Miller et al., 2002; Gallegos, Berumen \& Gomez-Meza, 2006; Davies et al., 2006; Grey et al., 2013; Hill-Briggs et al., 2011; Penckofer et al., 2012; Fitzner et al., 2014; Siminerio et al., 2008).

Beberapa penelitian tentang pengembangan program edukasi diabetes juga dilakukan di Indonesia, antara lain adalah pemberian supportive educative programe, self management intervention, tatalaksana diabetes dengan pendekatan teori model Behavioral System Dorothy E. Johnson, dan penerapan Health Action Process Approach (Darmansyah et al., 2013; Kholifah, 2014; Aini et al., 2011; Kusnanto et al., 2015). Beberapa penelitian tersebut berhasil meningkatkan pengetahuan, pemahaman, efikasi diri, perawatan diri, regulasi diri, kepatuhan, dan menurunkan kadar glukosa darah penderita DMT2.

Psikoedukasi merupakan salah satu dari bentuk edukasi, yang dapat dilakukan pada individu, keluarga, dan kelompok yang fokus pada mendidik respondennya mengenai tantangan signifikan 
dalam hidup, membantu responden mengembangkan sumber-sumber dukungan dan dukungan sosial dalam menghadapi tantangan tersebut, dan mengembangkan keterampilan koping untuk menghadapi tantangan tersebut (Griffith, 2006 dalam Walsh, 2010). Penerapan psikoedukasi untuk penderita DMT2 di Indonesia masih terbatas. Selama ini psikoedukasi lebih banyak difokuskan untuk mengintervensi masalah-masalah psikologis (Raudhoh, 2013).

Modifikasi Psikoedukasi (MP) dalam penelitian ini dirancang menggunakan gabungan beberapa konsep teori yaitu konsep edukasi, psikoterapeutik, dukungan sosial keluarga, teori goal attainment, dan psikoneuroimunologi untuk menyentuh seluruh aspek individu penderita DMT2 secara holistik. Penerapan MP pada penderita DMT2 dan keluarga juga mempertimbangkan kebudayaan dan karakter masyarakat Pulau Madura khususnya Kota Sumenep, yang pada umumnya memiliki ikatan emosional yang sangat kuat dengan kerabat atau keluarga (balab kerabah), dan cenderung lebih nyaman berkomunikasi dengan menggunakan bahasa Madura.Penelitian ini bertujuan untuk menganalisis pengaruh pemberian MP terhadap perilaku pengelolaan diabetes mandiri, dukungan keluarga, dan kadar glukosa darah penderita DMT2.

\section{METODE PENELITIAN}

Penelitian ini menggunakan quasy experiment - preandpost test control group design. Populasi adalah seluruh penderita DMT2 yang sedang menjalani rawat jalan di Poli Penyakit Dalam RSUD Dr. H. Moh. Anwar Sumenep. Sampel adalah penderita DMT2 $(\mathrm{n}=40)$ beserta keluarganya $(\mathrm{n}=40)$ yang memenuhi kriteria inklusi: 1) didiagnosis DMT2 $\leq 5$ tahun, 2) berusia 20-59 tahun, 3) rerata kadar glukosa darah acak $\geq 160 \mathrm{mg} / \mathrm{dl}$ atau rerata kadar glukosa darah puasa $\geq 140 \mathrm{mg} / \mathrm{dl}$ selama 2 bulan terakhir, 4) memiliki keluarga dekat, 5) dapat berbahasa Indonesia atau Madura. Sampel didapatkan dengan menggunakan teknik consecutive sampling.

Pengelompokan sampel $(\mathrm{n}=40)$ menjadi kelompok kontrol $(\mathrm{K}=20)$ dan kelompok perlakuan $\left(K^{\prime}=20\right)$ dilakukan secara acak (random). Kelompok perlakuan diberi intervensi MP, sedangkan kelompok kontrol diberi edukasi diabetes sesuai dengan SOP yang ada di Rumah Sakit.Pelaksanaan MP adalah di masingmasing rumah responden. Alat dan bahan 
yang digunakan dalam MP adalah media power point presentation (PPT) dan booklet.Pada kelompok kontrol edukasi diabetes hanya dilakukan satu (1) tahap sesuai dengan SOP yang dijalankan di rumah sakit dengan menggunakan media PPT dan leaflet.

MP tahap ke 1 dilakukan pengumpulan data pre-test yang meliputi pengambilan sampel darah vena untuk pemeriksaan kadar glukosa darah, dilanjutkan dengan data perilaku pengelolaan diabetes mandiri, serta dukungan keluarga (dengan alat ukur kuisioner). MP tahap 2 dilakukan pemberian edukasi tentang DMT2 secara komprehensif. MP tahap 3 dilakukan pemberian latihan cara mengelola diabetes secara mandiri. Pengukuran perilaku pengelolaan diabetes mandiri, kadar glukosa darah, dan dukungan keluarga untuk data post-test dilakukan setelah MP tahap ke 3 dan tahap monitoring selama tiga (3) minggu, baik pada kelompok perlakuan maupun kelompok kontrol. Pemeriksaan kadar glukosa darah dilakukan di Laboratorium. Data dianalisis dengan menggunakan Paired T-Test, Independen t-test, Wilcoxon Signed Rank test, dan Mann Whitney-U testdengan derajat kemaknaan $\mathrm{p} \leq 0,05$.

\section{HASIL}

Karakteristik umum responden penderita DMT2 disajikan dalam Tabel 1, sedangkan karakteristik keluarga disajikan dalam Tabel 2.Karakteristik umum penderita DMT2 meliputi umur, jenis kelamin, pendidikan, pekerjaan, penghasilan, lama DMT2, paparan informasi, dan perasaan terhadap penyakit DMT2 yang dialami. Karakteristik umum keluarga meliputi umur, jenis kelamin, pendidikan dan pekerjaan. Hasil uji homogenitas karakteristik umum baik pada responden penderita DMT2 maupun responden keluarga pada seluruh kategori memiliki nilai $\mathrm{p}>0,05$ yang berarti bahwa tidak ada perbedaan yang signifikan pada seluruh karakteristik umum kelompok perlakuan dan kontrol.

Hasil uji beda sampel tidak berpasangan (independent) sebelum perlakuan (pre-test), nilai $\mathrm{p}>\alpha \quad(\alpha=0,05)$ ditemukan pada semua variabel yaitu perilaku pengelolaan diabetes mandiri $(p=0,956)$, dukungan keluarga $(p=0,260)$, dan kadar glukosa darah (KGD) $(p=0,051)$ (Tabel. 3). Hal ini menunjukkan bahwa pada pre-test tidak ada perbedaan perilaku pengelolaan diabetes mandiri, dukungan keluarga, dan KGD antara kelompok perlakuan dan 
kelompok kontrol. Hasil uji beda sampel tidak berpasangan (independent) setelah perlakuan (post-test), nilai $\mathrm{p}<\alpha \quad(\alpha=0,05)$ ditemukan pada variabel dukungan keluarga $(p=0,016)$, sedangkan nilai $\mathrm{p}>\alpha$ ditemukan pada variabel perilaku pengelolaan diabetes mandiri $(p=0,214)$ dan KGD (0,465) (Tabel. 3). Hal ini menunjukkan bahwa pada post-test ada perbedaan pemahaman, efikasi diri, dan dukungan keluarga antara kelompok perlakuan dan kelompok kontrol setelah intervensi.

Tabel 1. Distribusi karakteristik responden penderita DMT2 kelompok perlakuan dan kelompok kontrol

\begin{tabular}{|c|c|c|c|c|c|c|}
\hline \multirow{2}{*}{\multicolumn{2}{|c|}{ Karakteristik Umum }} & \multicolumn{2}{|c|}{ Perlakuan } & \multicolumn{2}{|c|}{ Kontrol } & \multirow[t]{2}{*}{ Nilai $p$} \\
\hline & & \multirow{2}{*}{$\frac{F}{1}$} & \multirow{2}{*}{$\begin{array}{l}\% \\
5\end{array}$} & \multirow{2}{*}{$\frac{F}{-}$} & \multirow{2}{*}{$\frac{\%}{-}$} & \\
\hline Umur (tahun) & $34-40$ & & & & & \multirow{4}{*}{0,523} \\
\hline & $41-47$ & 6 & 30 & 3 & 15 & \\
\hline & $48-54$ & 8 & 40 & 14 & 70 & \\
\hline & $55-60$ & 5 & 25 & 3 & 15 & \\
\hline \multirow[t]{2}{*}{ Jenis Kelamin } & Lelaki & 7 & 35 & 8 & 40 & \multirow[b]{2}{*}{ - } \\
\hline & Perempuan & 13 & 65 & 12 & 60 & \\
\hline \multirow[t]{3}{*}{ Pendidikan } & Dasar & 10 & 50 & 13 & 65 & \multirow{3}{*}{0,567} \\
\hline & Atas & 7 & 35 & 4 & 15 & \\
\hline & PT & 3 & 15 & 3 & 20 & \\
\hline \multirow[t]{6}{*}{ Pekerjaan } & PNS & 3 & 15 & 4 & 20 & \multirow{6}{*}{0,184} \\
\hline & Wiraswasta & 5 & 25 & 3 & 15 & \\
\hline & Buruh & - & - & 3 & 15 & \\
\hline & Petani & 2 & 10 & 5 & 25 & \\
\hline & $\mathrm{TB}$ & 9 & 49 & 5 & 25 & \\
\hline & Pensiun & 1 & 5 & - & - & \\
\hline \multirow[t]{4}{*}{ Penghasilan } & $<\mathrm{Rp} 500 \mathrm{k}$ & 11 & 55 & 9 & 45 & \multirow{4}{*}{0,710} \\
\hline & $\mathrm{Rp} 500 \mathrm{k}-1.000 \mathrm{k}$ & 3 & 15 & 5 & 25 & \\
\hline & Rp $1.000 \mathrm{k}-3.000 \mathrm{k}$ & 2 & 10 & 2 & 10 & \\
\hline & $>\mathrm{Rp} 3000 \mathrm{k}$ & 4 & 20 & 4 & 20 & \\
\hline \multirow[t]{3}{*}{ Lama DM } & $<1$ tahun & 4 & 20 & 6 & 30 & \multirow{3}{*}{0,791} \\
\hline & $1-3$ tahun & 6 & 30 & 7 & 35 & \\
\hline & $>3$ tahun & 10 & 50 & 7 & 35 & \\
\hline \multirow{2}{*}{$\begin{array}{l}\text { Paparan } \\
\text { Informasi }\end{array}$} & Pernah & 2 & 10 & 11 & 55 & \multirow[b]{2}{*}{ - } \\
\hline & Tidak & 18 & 90 & 9 & 45 & \\
\hline \multirow[t]{2}{*}{ Perasaan } & Biasa & 13 & 65 & 14 & 70 & \\
\hline & Cemas & 7 & 35 & 6 & 30 & \\
\hline
\end{tabular}

Sumber: Data Primer 2016

Hasil uji beda sampel berpasangan

(dependent) pada kelompok perlakuan, nilai $\mathrm{p}<\alpha \quad(\alpha=0,05)$ ditemukan pada semua variabel yaitu perilaku pengelolaan diabetes mandiri $(p=0,004)$, dukungan keluarga $(p=0,001)$, dan KGD $(p=0,013)$ 
(Tabel. 3). Hal ini menunjukkan bahwa ada perbedaan signifikan antar nilai pre-test dan post-test kelompok perlakuan pada semua variabel yang diukur .Hasil uji beda sampel berpasangan (dependent) pada kelompok kontrol, nilai $\mathrm{p}<\alpha \quad(\alpha=0,05)$ ditemukan pada variabel dukungan keluarga $(\mathrm{p}=0,000)$, sedangkan nilai $\mathrm{p}>\alpha$ ditemukan pada variabel perilaku pengelolaan diabetes mandiri $(\mathrm{p}=0,378)$ dan KGD ( $p=0$,997) (Tabel. 3). Hal ini menunjukkan bahwa ada perbedaan antara nilai pre-test dan post-test kelompok kontrol pada variabel dukungan keluarga

Tabel 2 Distribusi karakteristik responden keluarga kelompok perlakuan dan kelompok kontrol

\begin{tabular}{llccccc}
\hline \multirow{2}{*}{ Karakteristik Umum } & \multicolumn{2}{c}{ Perlakuan } & \multicolumn{2}{c}{ Kontrol } & \multirow{2}{*}{ Nilai $p$} \\
& & $\mathrm{~F}$ & $\%$ & $\mathrm{~F}$ & $\%$ & \\
\hline \multirow{2}{*}{ Umur (tahun) } & $15-23$ & 3 & 15 & 3 & 15 & \\
& $24-32$ & 4 & 20 & 1 & 5 & 0 \\
& $33-41$ & 3 & 15 & 7 & 35 & \\
& $42-50$ & 6 & 30 & 7 & 35 & \\
& $51-59$ & 4 & 20 & - & - & \\
& $60-67$ & - & - & 2 & 10 & \\
\hline Jenis Kelamin & Lelaki & 15 & 75 & 10 & 50 & - \\
& Perempuan & 5 & 25 & 10 & 50 & \\
\hline Pendidikan & Dasar & 10 & 50 & 11 & 55 & \\
& Atas & 5 & 25 & 7 & 35 & 0,418 \\
& PT & 5 & 25 & 2 & 10 & \\
\hline Pekerjaan & PNS & 3 & 15 & 5 & 25 & \\
& Wiraswasta & 1 & 5 & 3 & 15 & \\
& Buruh & 3 & 15 & 1 & 5 & \multirow{2}{*}{0,331} \\
& Petani & 3 & 15 & 5 & 25 & \\
& TB & 9 & 45 & 4 & 20 & \\
& Pensiun & - & - & 1 & 5 & \\
& Pelajar & 1 & 5 & 1 & 5 & \\
\hline
\end{tabular}

Sumber: Data Primer 2016

Tabel. 4 menunjukkan bahwa nilai GDA pada kelompok kontrol cenderung mengalami peningkatan setelah diberi intervensi, sedangkan pada kelompok perlakuan cenderung mengalami penurunan setelah diberi intervensi MP.

\section{PEMBAHASAN}

Pemberian Modifikasi Psikoedukasi (MP) meningkatkan perilaku pengelolaan diabetes mandiri. Hasil penelitian ini sesuai dengan beberapa penelitian sebelumnya yang menyatakan bahwa Self Management Intervention, pemberian 
motivasi dan edukasi dengan pendekatan Model Behavioral System Dorothy E. Johnson, dan HAPA meningkatkan kepatuhan atau perilaku pasien dalam tatalaksana DMT2 (Aini et al., 2011; Kholifah, 2013, dan Kusnanto et al., 2015). Rogers (1974) dalam Notoatmodjo (2003) menjelaskan pengalaman dari penelitian terbukti bahwa perilaku yang didasari oleh pengetahuan akan lebih langgeng dari pada perilaku yang tidak didasari oleh pengetahuan.

Tabel 3. Hasil Analisis Statistik Uji Beda kelompok Perlakuan dan Kontrol pada Pretest dan Post-test

\begin{tabular}{ccccc}
\hline Variabel & $\begin{array}{c}\text { Uji beda } \\
\text { sampel tidak } \\
\text { berpasangan } \\
\text { pre-test }\end{array}$ & $\begin{array}{c}\text { Uji beda } \\
\text { sampel tidak } \\
\text { berpasangan } \\
\text { post-test }\end{array}$ & $\begin{array}{c}\text { Uji beda } \\
\text { sampel } \\
\text { berpasangan } \\
\text { K.Perlakuan }\end{array}$ & $\begin{array}{c}\text { Uji beda } \\
\text { sampel } \\
\text { berpasangan } \\
\text { K.Kontrol }\end{array}$ \\
\hline $\begin{array}{c}\text { Perilaku } \\
\text { pengelolaan } \\
\text { diabetes } \\
\text { mandiri }\end{array}$ & $* 0,956$ & $* * 0,214$ & $* * * 0,004$ & $* * * * 0,378$ \\
\hline $\begin{array}{c}\text { Dukungan } \\
\text { keluarga }\end{array}$ & $* * 0,260$ & $* 0,016$ & $* * * * 0,001$ & $* * * 0,000$ \\
\hline $\begin{array}{c}\text { Kadar Glukosa } \\
\text { darah }\end{array}$ & $* * 0,051$ & $* * 0,465$ & $* * * 0,013$ & $* * * 0,997$ \\
\hline Ketan
\end{tabular}

Keterangan:

* Independen sample T-Test

** Mann WhitneyU test

*** Paired T-test

**** Wilcoxon signed rank

Tabel 4. Distribusi nilai GDA sebelum dan sesudah intervensi di Poli Penyakit Dalam RSUD Dr. Moh. Anwar Sumenep tanggal 25 Mei - 26 Juni 2016

\begin{tabular}{|c|c|c|c|c|}
\hline Kelompok & $\mathrm{F}$ & Mean & $\mathrm{SD}$ & $\mathrm{p}$ value \\
\hline \multicolumn{5}{|l|}{ Kelompok Kontrol } \\
\hline Sebelum (pre test) & 20 & 254,85 & 78,49 & $\begin{array}{c}\text { Paired T Test } \\
0,997\end{array}$ \\
\hline Sesudah (post test) & 20 & 254,90 & 93,57 & \\
\hline \multicolumn{5}{|l|}{ Kelompok Perlakuan } \\
\hline Sebelum (pre test) & 20 & 307,50 & 91,43 & $\begin{array}{c}\text { Paired T Test } \\
0,013\end{array}$ \\
\hline Sesudah (post test) & 20 & 278,85 & 109,14 & \\
\hline
\end{tabular}

Pemberian MP dalam penelitian ini menggunakan beberapa konsep consumer behaviour yaitu dengan memodifikasi karakteristik pesan dan lingkungan sebagai upaya agar pesan dapat tersampaikan secara efektif kepada 
penerima. Modifikasi karakteristik pesan yang dilakukan yaitu menyajikan materi menggunakan media power point presentation (dengan laptop), dilengkapi dengan gambar yang menunjang retensi informasi responden. Materi tentang diabetes disampaikan secara komprehensif dengan harapan responden akan memahami penyakit diabetes secara menyeluruh, denganmenggunakan bahasa sederhana yang mudah dimengerti dan sesuai dengan tingkat pendidikan responden.

Perawat edukator dilatih terlebih dahulu untuk bisa menerapkan MP secara komunikatif dan menarik perhatian responden (penderita DMT2 dan keluarga). Empat prinsip digunakan oleh perawat edukator dalam menghadapi responden, yaitu meliputi: menyebut nama responden berulang (untuk menghargai responden dan membuat responden merasa menjadi orang yang penting dalam pelaksanaan edukasi ini), tersenyum, selalu menanyakan kepada responden apakah yang disampaikan oleh perawat edukator dapat dimengerti (di setiap poin bahasan), dan memberikan pujian saat responden memperlihatkan antusiasme dan ekspresi memahami materi yang disampaikan.
Intervensi MP yang diberikan dalam penelitian ini didasarkan pada teori Goal attainment King dan psikoneuroimunologi. Hukum King (1997) interaksi perawatpasien yaitu perawat dan pasien berinteraksi dan melakukan transaksi dalam situasi keperawatan berdasarkan pada setiap persepsi masing-masing individu, komunikasi terarah, dan tujuan dihargai. Pemberian intervensi MP juga sesuai dengan konsep persepsi dalam teori Psikoneuroimunologi. Persepsi merupakan kemampuan untuk memahami atau mengkonsepkan stresor yang diterima, yang menghasilkan suatu kognisi (pengertian), yang dapat menimbulkan respon terhadap stres berupa modulasi respon imun (Putra, 2011). Pada MP tahap 2, perawat edukator mulai memberikan edukasi sesuai dengan kebutuhan belajar responden. Materi yang disampaikan kepada penderita DMT2 pada tahap 2 ini adalah "Segala hal tentang DMT2".Intervensi MP yang diberikan dalam penelitian ini mengandung materi motivasi untuk meningkatkan keyakinan diri dalam menghadapi diabetes.

Materi MP tahap 3 yang diberikan pada responden kurang lebih sama dengan standar edukasi tentang DSME. 
Peningkatan perilaku pengelolaan diabetes mandiri berdasarkan hasil pre test dan post test signifikan pada kelompok perlakuan, sedangkan pada kelompok kontrol perilaku pengelolaan diabetes mandiri cenderung menurun. Penurunan perilaku pengelolaan diabetes mandiri pada kelompok perlakuan terjadi pada responden no.13 (25,00 menjadi 23,00). Responden no.13 menjelaskan pada saat evaluasi bahwa mengalami kesulitan untuk mengontrol makan pada saat berbuka puasa. Data menunjukkan bahwa responden memiliki tingkat pendidikan dasar (SD) dan bekerja sebagai petani.

Pemberian intervensi MP dapat meningkatkan perilaku pengelolaan diabetes mandiri penderita DMT2. Perilaku pengelolaan diabetes mandiri seorang individu akan berpengaruh secara langsung terhadap kadar glukosa darah. Individu yang memiliki perilaku pengelolaan diabetes yang baik cenderung akan mengalami perbaikan kadar glukosa darah, begitu pula sebaliknya. Kadar glukosa darah yang tidak terkontrol akan menjadi akar dari munculnya berbagai komplikasi DMT2.

Pemberian MP juga meningkatkan pemberian dukungan keluarga. Sesuai penelitian sebelumnya bahwa pemberian psikoedukasi pada keluarga klien yang mengalami isolasi sosial dapat meningkatkan kemampuan afektif dan psikomotor keluarga dalam merawat klien yang mengalami isolasi sosial (Wiyati, Wahyuningsih, \& Widayanti, 2010). Keikusertaan semua anggota keluarga untuk memberikan penguatan dalam jangka yang lama (Fitriani, 2011). Dukungan keluarga akan melindungi individu tehadap efek negatif dari depresi dan dukungan keluarga secara langsung akan mempengaruhi status kesehatan individu.

Caplan (1989) menjelaskan beberapa jenis dukungan keluarga, yaitu dukungan emosional, dukungan penilaian, dukungan instrumental, dan dukungan informasional. Beberapa faktor mempengaruhi dukungan keluarga yang meliputi faktor internal dan eksternal. Faktor internal antara lain meliputi tahap perkembangan, pendidikan atau tingkat pengetahuan, faktor emosi, dan spiritual. Faktor eksternal yang dapat mempengaruhi dukungan keluarga antara lain adalah praktik di keluarga, faktor sosioekonomi, dan latar belakang budaya. 
Intervensi MP yang diberikan dalam penelitian ini juga mengikutsertakan keluarga terdekat penderita DMT2 mulai dari tahap awal hingga tahap akhir. Materi tentang pentingnya dukungan keluarga bagi penderita DMT2 diberikan setelah materi cara mengelola diabetes secara mandiri. Perawat edukator memberikan beberapa contoh konkrit kepada keluarga penderita DMT2 tentang bagaimana cara memberikan dukungan keluarga yang meliputi dukungan emosional, dukungan penilaian, dukungan instrumental, dan dukungan informasional sesuai dengan kondisi masing-masing keluarga.

Pemberian dukungan keluarga responden penelitian ini cenderung mengalami perbaikan pada post-test. Faktor tingkat pendidikan tidak terlalu berpengaruh pada pemberian dukungan keluarga. Faktor emosi cukup memberikan pengaruh pada pelaksanaan pemberian dukungan keluarga, itulah sebabnya keluarga yang diikutsertakan dalam penelitian ini diupayakan adalah orang terdekat penderita DMT2. Sedangkan faktor sosioekonomi dan latar belakang budaya sangat mempengaruhi praktik pemberian dukungan keluarga. Keluarga dengan tingkat ekonomi rendah cenderung mengalami kesulitan dalam pemberian dukungan instrumental, yang akhirnya juga berpengaruh pada pemberian dukungan motivasional. Hal ini disebabkan karena keluarga yang merasa tidak mampu memberikan bantuan secara nyata (instrumental), menganggap pemberian dukungan emosional dan dukungan penilaian tidak akan memberikan pengaruh. Keluarga dengan sosioekonomi rendah masih bisa meningkatkan pemberian dukungan informasional setelah diberi intervensi MP. Keluarga dengan latar belakang budaya dengan pola komuniksi atau bahasa yang sedikit kaku, tidak terbiasa mengatakan kalimat-kalimat motivasi atau penilaian pada keluarganya. Hal ini juga menjadi suatu hal yang cukup sulit dilakukan perubahan. Akan tetapi secara keseluruhan, responden keluarga dalam penelitian ini dapat meningkatkan pemberian dukungan keluarga pada penderita DMT2 walaupun dengan model atau cara yang berbeda sesuai dengan adat atau pola kebiasaan di dalam masing-masing keluarga. Dukungan keluarga yang diberikan secara konsisten dan benar akan meningkatkan rasa percaya diri dan kesejahteraan psikologis penderita DMT2. 
Peningkatan pemahaman, efikasi diri, dukungan keluarga, dan perilaku pengelolaan diabetes mandiri pada penderita DMT2 menunjang perbaikan kadar glukosa darah. Hasil penelitian menunjukkan bahwa terdapat perbedaan antara nilai GDA sebelum dan sesudah diberikan intervensi MP, sedangkan pada kelompok kontrol tidak terdapat perbedaan antara nilai GDA sebelum dan sesudah diberikan intervensi.Hasil penelitian ini didukung oleh beberapa penelitian lain. Pemberian motivasi dan edukasi dengan pendekatan Model Behavioral System Dorothy E. Johnson menurunkan kadar glukosa darah puasa dan kadar glukosa darah 2 jam PP pada penderita DMT2 (Aini et al. 2011). Penerapan Health Action Process Approach (HAPA) dapat menurunkan kadar glukosa darah puasa secara signifikan pada penderita DMT2 di Puskesmas Krian Sidoarjo (Kusnanto et al. 2015).

Glukosa darah acak merupakan salah satu indikator yang diukur untuk menunjukkan kondisi penderita DMT2. Kriteria pengendalian DM menurut Perkeni (2011) salah satunya adalah kadar glukosa darah acak. Kadar glukosa darah acak pada penelitian ini diukur minimal 3 jam setelah makan sahur atau minimal 3 jam setelah sarapan pagi.

Glukosa darah penderita DMT2 menurun secara langsung oleh beberapa hal yaitu seperti diet, aktivitas fisik, penggunaan obat antidiabetes dan insulin. Secara tidak langsung kadar glukosa darah penderita DMT2 juga dipengaruhi oleh aspek kognitif, persepsi, kondisi psikologis penderita, dukungan sosial, serta kualitas pelayanan kesehatan. Perubahan perilaku diawali dari pemahaman yang benar terhadap suatu hal (didapatkan dari belajar), yang selanjutnya pemahaman (ranah kognitif) ini akan memberikan dampak pada ranah psikologis atau emosional. Ranah psikologis atau emosional ini akan membangkitkan keinginan, motivasi, dan kepercayaan diri seseorang untuk melakukan tindakan (action). Ditambah dengan dukungan sosial dari keluarga yang akan membantu meningkatkan kepercayaan diri penderita DMT2 untuk melakukan pengelolaan diabetes mandiri dengan baik.Menjalankan pengelolaan diabetes secara mandiri dengan pemahaman yang benar, keyakinan dan kesadaran yang positif, akan mendukung perilaku yang positif dan pada respon biologisnya akan menstimulasi jalur 
HPA-axis yang nantinya akan berdampak akhir pada penurunan sekresi hormon kortisol dan hormon stres lainnyasehingga kadar glukosa darah menurun (Freeman \& Lawliw, 2001).

Beberapa responden dalam penelitian ini yang mengalami peningkatan kadar glukosa darah acak saat pemeriksaan darah post test mengatakan bahwa mengalami kesulitan untuk mengontrol makanan pada saat berbuka puasa, terutama untuk menghindari minuman manis. Responden juga mengatakan bahwa sajian makanan pada saat berbuka puasa menjadi lebih banyak dan beraneka ragam dari biasanya (di luar bulan Ramadhan) sehingga kesulitan untuk menahan diri.

Akan tetapi secara umum responden mengalami penurunan kadar glukosa darah. Hal ini dapat disebabkan oleh materi yang diberikan pada saat pemberian edukasi juga menyentuh ranah psikologis dan emosi penderita DMT2, sehingga penderita DMT2 mungkin memiliki perasaan takut glukosa darah naik, atau perasaan yakin mampu mengendalikan, atau perasaan semangat untuk meningkatkan status kesehatnnya.
Glukosa darah menjadi kunci penilaian diabetes. Glukosa yang cenderung menurun dan menjadi terkontrol akan membantu mencegah terjadinya komplikasi diabetes mellitus baik komplikasi mikro maupun makrovaskuler serta meningkatkan derajat kesehatan dan kualitas hidup penderita DMT2.

\section{KESIMPULAN}

Pemberian Modifikasi Psikoedukasi meningkatkan perilaku pengelolaan diabetes mandiri dan dukungan keluarga, serta menurunkan kadar glukosa darah acak penderita DMT2 di Poli Penyakit Dalam RSUD dr. H. Moh. Anwar Sumenep.

Model pendidikan diabetes seperti Modifikasi Psikoedukasi yang melibatkan aspek kognitif, emosi (psikologis) dan sosial budaya klien perlu diterapkan di pelayanan kesehatan sehingga dapat mengefektifkan pendidikan kesehatan yang diberikan kepada penderita DMT2.

\section{REFERENSI}

Aini, N., Fatmaningrum, W., \& Yusuf, A. (2011). Upaya meningkatkan perilaku pasien dalam tatalaksana diabetes mellitus dengan pendekatan teori model behavioral system Dorothy E. Johnson. Jurnal Ners, 6(1), 1-10. 
Al-Khawaldeh, O. A., Al-Hassan, M. A., \& Froelicher, E. S. (2012). SelfEfficacy, Self-Management, and Glycemic Control in Adults with Type 2 Diabetes Mellitus. Journal of Diabetes and Its Complication. No. 12, 10-16.

Bandura, A. (1997). Self-efficacy: The exercise of control. Macmillan.

Bastable, S. B. (2002). Perawat sebagai pendidik: prinsip-prinsip pengajaran dan pembelajaran. Jakarta: EGC, 139140.

Caplan, G. (1989). Recent developments in crisis intervention and the promotion of support service. Journal of Primary Prevention, 10(1), 3-25.

Coffey, J. T., Brandle, M., Zhou, H., Marriott, D., Burke, R., Tabael, B. P., Herman, W. H. (2002). Valuing health-related quality of life in diabetes. Diabetes Care, 25, 22382243.

Darmansyah, A. F., Nursalam, \& Suharto. (2013). Efektivitas Supportive Educative terhadap peningkatan self regulation, self efficacy, dan self care agency dalam kontrol glikemik penderita diabetes mellitus tipe 2. Jurnal Ners , 253270.

Davies, M. J., Heller, S., Skinner, T. C., Campbell, M. J., Carey, M. E., Cradock, S., . . Khunti, K. (2006). Effectiveness of the Diabetes Education and Self Management for Ongoing and Newly Diagnosed (DESMOND) programme for people with newly diagnosed type 2 diabetes: cluster randomised controlled trial. Bio Medical Journal, 1-11.
Fitriani, K. I. (2011). Kajian Teori Sumber Dukungan Keluarga(Doctoral dissertation, Tesis. Malang: Universitas Islam Negeri Maulana Malik Ibrahim).

Fitzner, K. K., Heckinger, E., Tulas, K. M., Specker, J., \& McKoy, J. (2014). Telehealth technologies: changing the way we deliver efficacious and cost-effective diabetes self-management education. Journal of health care for the poor and underserved, 25(4), 18531897.

Gallegos, E. C., Berumen, F. O., \& Gomez-Meza, M. V. (2006). Metabolic control of adults with type 2 diabetes mellitus through education and counseling. Journal of Nursing Scholarship, 344-351.

Grey, M., Whittemore, R., Jeon, S., Murphy, K., Faulkner, M. S., \& Delamater, A. (2013). Internet Psycho-Education Programs improve outcomes in youth with type 1 diabetes. Diabetes Care, 36, 2475-2482.

Hill-Briggs, F., Lazo, M., Peyrot, M., Doswell, A., Chang, Y. T., Hill, M. N., ... \& Brancati, F. L. (2011). Effect of problem-solving-based diabetes self-management training on diabetes control in a low income patient sample. Journal of general internal medicine, 26(9), 972.

Ilyas, E.I., 2009. Olah Raga Diabetesi. Dalam : Soegondo, S., Soewondo,P., Subekti, I., Penatalaksanaan Diabetes Melitus Terpadu. Fakultas Kedokteran Universitas Indonesia, Jakarta: 73,76

Keeratiyutawong, P., Hanucharurnkul, S., Boonchauy, W., Phumleng, B., \& Muangkae, W. (2005). 
Effectiveness of a supportive educative program on diabetic control, perceived self-care efficacy, and body mass index in persons with type 2 diabetes mellitus. Thai Journal of Nursing Research, 9(1), 1-12.

Kholifah, S. N. (2014). Self management intervention sebagai upaya peningkatan kepatuhan pada penderita DM. Jurnal Ners, 9 (1), 143-150.

King, I. M. (1997). King's theory of goal attainment in practice. Nursing Science Quarterly, 10(4), 180-185.

Kusnanto, Kurnia, I. D., \& Prasetia, D. I. (2015). Penerapan "Health action proccess approach" untuk meningkatkan kepatuhan diet penderita DM tipe 2. Jurnal Ners, 10 (2), 272-278.

Miller, C. K., Edwards, L., Kisslling, G., \& Sanville, L. (2002). Nutrition education improves metabolic outcomes among older adults with diabetes mellitus: results from a randomized controlled trial. Preventive Medicine, 34, 252-259.

Notoadmojo, P. D. (2003). Pendidikan dan perilaku kesehatan. Jakarta: PT Rineka Cipta.

Paddison, C. A. M., Alpass, F. M., \& Stephens, C. V. (2008). Psychological factors account for variation in metabolic control and perceived quality of life among people with type 2 diabetes in New Zealand. International journal of behavioral medicine, 15(3), 180-186.

Penckofer, S. M., Ferrans, C., Byrn, M., Harrison, R. P., \& Durazo-Arvizu, R. A. (2012). A Psychoeducational Intervention (SWEEP) for
Depressed Women with Diabetes. Behavioral Medicine, 192-206.

Perkumpulan Endokrinologi Indonesia. (2011). Konsensus pengelolaan dan pencegahan diabetes mellitus tipe 2 di Indonesia. Perkeni, (hal. 4-10, 1529).

Raudhoh, S. (2013). Psikoedukasi: Intervensi dan Rehabilitasi dan Prevensi. Artikel Penelitian. Magister Profesi Psikologi Universitas Padjadjaran.

Siminerio, L. M. (2008). Approaches to help people with diabetes overcome barriers for improved health outcomes. The Diabetes Educator, 34 (1), 18-24.

Sratton, I. M., Adler, A. I., Neil, H. A., Matthews, D. R., Manley, S. E., Cull, C. A., Holman, R. R. (2000). Association of glycaemia with macrovascular and microvascular complication of type 2 diabetes (UKPDS 35): prospective observational study. British Medical Journal, 321, 405-412.

Surya, K. W., Yuniarti, K. W., \& MedSc, M. (2015). Pelatiban pasien terpusat dengan pendekatan common sense model dalam meningkatkan manajemen diri dan efikasi diri pasien diabetes mellitus tipe 2 (Doctoral dissertation, Universitas Gadjah Mada).

Walsh, J. F. (2010). Psychoeducation in mental health. Lyceum Books.

Wiyati, R., Wahyuningsih, D., \& Widayanti, E. D. (2010). Pengaruh Psikoedukasi Keluarga Terhadap Kemampuan Keluarga dalam Merawat Klien Isolasi Sosial. Jurnal Keperawatan Soedirman. Volume 5, No. 2, 85-94. 